\title{
THE IMPLEMENTATION OF CHARACTER EDUCATION IN PREPARING THE STUDENTS TO FACE INDUSTRIAL REVOLUTION 4.0 -A RESEARCH OF ENGLISH FOR ENGINEERING IN DARMA AGUNG UNIVERSITY
}

\author{
Corry Ester Margaret Siagian \\ University Of Darma Agung \\ coysmart@yahoo.co.id
}

\begin{abstract}
This study is about the implementation of how the lecturer can contribute as an agent of transferring culture and knowledge in preparing the students to face the Industrial Revolution 4.0 by doing the Character Education to the students of Mechanical Engineering in learning English for Engineering Students. This study is done in faculty of Engineering at the University of Darma Agung, Medan. It is a qualitative research and used documentation and questioner technique in collecting the data needed. It is revelead that the lecturer implements character education by being a role model, building a targeted learning culture and atmosphere, giving punishment and appraisal and using the appropriate teaching materials and method based on the needs of the students and the targeted workplace.
\end{abstract}

Keywords : implementation, character, education

\section{BACKGROUND}

Recently, Indonesia has designed 'Making Indonesia 4.0' as an integrated roadmap to implement a number of strategies to enter the Industry 4.0 era. The roadmap requires collaborative actions among multiple stakeholders that range from government institutions, associations and industry players, to academic elements.

The implementation of Industry 4.0 aims to achieve the great national aspirations, which are bringing Indonesia upward to reach 10 biggest economies by 2030. To reach this, Indonesian government has formulated ten national priority strategies as follow: reforming the flow of materials, industrial zone redesign, improvement of human resources quality, empowerment of Micro Small and Medium Enterprise (UMKM), incentives implementation on technology investment, formation of innovation ecosystem, attracting foreign direct investment, harmonization of policy and regulations, building the national digital infrastructure, and accommodating sustainability standard.

In the past, social rank depended on the ability to do physical work. Now, critical thinking and problem solving, communication, and collaboration are essential in this model of human motivation that drives the digital economy. Other non-cognitive skills such as persistence, self-control, and curiosity also play a role in the new stratification of class. In addition, there has been a steady change from innovations as tools that support a human's work, to those that take humans as moderators of machines and quality controllers of novel forms of artificial intelligence. In line with this, people have to have the digital talents to be ready to face the digital challenge.

In the new hybrid economy, there will be more room for human-to-human collaboration aided by immersive technological tools. Competition is not only determined by mastering the skill alone but must be based on strong character as a foundation in striving to advance human in order to be able to compete in the Industrial Revolution 4.0 era. Thereby,strengthening innovation, 
increasing competitiveness, having to work together as a team must be instilled early on, especially for students as future economic actors.

The lecturer who is actually an educator plays an important role. The lecturers are the most important figure who must address the changing time because the development of the Indonesian nation depends very much on the quality of its education and the relevance of the results of human resources of higher education with development needs and industry 4.0 must be balanced. That is why; they are the front guard in education at the university level to produce quality graduates according to the needs of the times.

The Old literacy (reading, writing, and arithmetic) as capital has been obtained. Now, no less important is understanding new literacy, the students have to learn them, namely data literacy, technology literacy, and human literacy (humanities, communication, positive thinking)

Everyone who wants to work must not stop to always innovate as a quick response to market desires as a consequence of living in a world full of information flow and tight technological competition. A very swift flow of information allows producers to more quickly find out market tastes and changes in the business environment. Companies that have valid information on the market can respond by developing new products that are in line with market desires as soon as possible. Students must be able to predict the next world trend. The ability to collaborate with others is also important. The ability to do strategies Observe, Emulate and Modify is also important.

Students not only need knowledge but also character. A person's success is not only seen in the competence of science (hard skill) but also supported by spiritual and emotional competence (soft skills). Education should not only focus on quantitative results but also on qualitative results, so the lecturer does not only pay attention to brain intelligence, but also spiritual intelligence and emotional intelligence. These three things are needed by students to be able to face the era industrial revolution 4.0.

Lecturers play an important role in realizing this national education goal. Building the character of students is not only the task of the lecturers of Pancasila, Citizenship, Ethics and Aesthetics but should be the responsibility of all educators in the student environment. Developing moral values in learning activities should also not be limited to text but developed into positive values carried out in everyday life.

This research is held to answer the question of the research that is: How do lecturers implement student character education in English learning?

\section{METHOD}

\subsection{Place of research subjects}

This research was carried out at the University of Darma Agung, the research subjects were lecturers in teaching English for the Engineering Students.

\subsection{Types of research}

This research is a qualitative research with a Research and Development Research. The learning process is in a natural setting and there is no special treatment from researchers for research subjects.

\subsection{Data collection}

Data collection is done with documentation and interviews. The data source is the English lecturer and the students in the Mechanical Engineering and documentation in the form of the Educational Literature Unit of the lecturer.

\subsection{Research instruments}

The main instrument of this 
research is the researcher herself who aims to find data and collect it directly from the data source. The auxiliary instrument is the lecturer documentation, namely the Teaching Unit for English lecturer education in English lecture. Another instrument is an instrument used to find out the purpose and the way the lecturer performs character education in the class.

\section{FINDINGS AND DISCUSSIONS}

\subsection{FINDINGS}

\subsubsection{The Lecturer is the Role Model}

One of the easiest ways to learn is to imitate. The lecturer is someone who always meets students especially when the learning class takes place. Therefore, by giving an example in person, the lecturer has first instilled the character herself. before inspiring his students. The lecturer educates characters through his life. How the lecturer speaks acts or behaves will always be a role model for the students. The characters that the lecturer wants to build through his responsibility as an educator can be seen from their interaction with students, their behavior, words, attitudes and actions that they showed are very effective to communicate in character education. In this case, the lecturer conveys the teaching, the norms and values of life that he lives through his behavior, speech, and responses to things happened. The lecturer implemented the character education by always setting an example for students of the character of discipline, curiosity, responsible, innovative, communicative, and giving a good respond to the need.

\subsubsection{Having curiosity}

The lecturer did these activities in the classroom

1. Lecturer shows that he is curious about something that he doesn't know

2. Lecturer asks questions about something related to students' needs about the lesson

3. Lecturer shows that he has curiosity about updated information related to the learning and teaching process

4. Lecturers always pay attention to students in a positive sense about various things (problems, new things, etc.)

\subsubsection{Being Innovative}

1. Lecturers always design student groupings in the execution of tasks / projects for the purpose of complementarities (the smart with the less intelligent; the talkative with the quiet)

2. Lecturers always create a pleasant and friendly class atmosphere

3. Lecturers always fill the learning process with things that happen on campus, society and nation

4. Lecturers get used to socializing and interacting with fellow students and the surrounding environment

5. Lecturers always have many ways and strategies in conducting the teaching and learning for the students

\subsubsection{Being Discipline}

1. The lecturer notifies the rules and consequences of violating the rules that have been explained in the explanation of the lecture contract

2. Lecturers are always present on time

3. Always check the attendance list signed by students

4. Stay consistent in implementing the rules that have been made

5. Give consequences to students who break the rules

6. Students will not enter the class if it's too late except for a special case

7. Lecturers are consistent with the time of the assignment, class attendance and others

8. Lecturers always wear uniforms as they are organized by the university

9. Lecturers always bond to students about the delay if there is a sudden campus activity

\subsubsection{Having a good communication}


1. Providing equal opportunities for each student to give their opinions

2. Providing understanding that dissenting is a natural thing and the student's faithfulness must respect the opinions of others

3. The lecturer appreciates every answer given by the student without underestimating if it is wrong

4. Lecturers stop students from interrupting other students who are giving opinions

5. The lecturer accustoms the student to raise his hand to interrupt but the student speaks only when he is welcome

6. Lecturers always listen attentively to each question and opinion of students

\subsubsection{Having a good respond to the needs}

1. Lecturers know the background of their general and specific student abilities

2. Lecturers know what areas are the difficulties and abilities of students

3. Lecturer knows the market needs of the ability that students should have

\subsubsection{Being Responsible}

1. Lecturers always plan, carry out the learning process, and assess and evaluate learning outcomes

2. Lecturers always carry out the learning process well

3. Lecturers always give assignments to be done by students

4. Lecturers admonish and give consequences to students who neglect to carry out their duties

5. Lecturers are always consistent in giving consequences to students who are lazy to do their jobs

6. Lecturers always provide equal opportunities for each student to become a leader in group work / partner

7. Always provide opportunities for students to take turns to be responsible for the roles needed in class

\subsubsection{Building the Targeted Learning}

\section{Culture and Atmosphere}

Introducing and familiarizing students with the characters that have been designed by the lecturers to be achieved by their students is another step than to set an example. The existence of implementing rules, habits of lecturers can create a culture of student character education. Lecturers give influence by shaping student culture. Lecturers not only teach what is right and what is wrong, but more than that, the lecturer instills habits about what is good so that students understand (cognitively) what is right and wrong, able to feel (affective) good and ordinarily do the habit (psychomotor). For example: praying at the beginning and the ending of learning, a culture of politeness when asking questions, culture of listening to questions and opinions with appreciation, and giving students confidence to explore themselves by not pressing or imposing their will on it.

\subsubsection{Discipline}

1. Lecturer always implements regulations consistently

2. Lecturer makes clear rules

3. Lecturer gives gifts or appreciation after students do something good or always following the rules

4. Lecturer invites the students to speak well even though he is angry

\subsubsection{Having curiosity}

1. Provide opportunities for students to ask questions

2. Never underestimate student questions even though sometimes they are not appropriate

3. Lecturers provide assignments that require students to explore information other than books

4. Lecturers are willing to re-explain the learning section that students do not understand well

5. Lecturers ask students questions to understand their understanding of the topics they are currently studying 


\subsubsection{Being Innovative}

1. Familiarizing the students to see opportunities in various ways

2. Encountering a concept or problem and confronting it with students and allowing students to issue as many ideas as possible to overcome problems

3. Teaching students about possible possibilities that can arise for every action taken by students in working on independent or group projects in the process of teaching and learning

4. Providing a friendly space as a place to fine-tune students' creative ideas in displaying their works

\subsubsection{Having a good Communication}

1. Familiarize students with listening to their friends when speaking

2. Invite students to think carefully about what they want to say or say when they argue or respond to friends' opinions

3. Invite students to speak politely

4. Teaching students to present their assignments well

\subsubsection{Having a good respond to the needs}

1. Lecturers familiarize students to care about things that are happening around

2. Lecturers invite students to provide answers that are in line with the things that are happening

3. Lecturers invite students to care about campus activities and off- campus activities.

\subsubsection{Giving Punishment and appraisal Punishment}

The leturer acts objectively and is not discriminatory. The consequences given are always related to errors. The lecturer stays focused on the problem so that the student knows clearly where the mistake is. The consequences given are always reasonable and reasonable, provide a learning experience, and also as a means to emphasize that student behavior is wrong and must be corrected immediately while maintaining student self-esteem.

The essence of punishment and appraisal among the students are there to ensure the students are on the right tract to take responsibility for themselves and make them aware of their life so that they know and act the targeted behavior (doing good things) and stop doing or involve in bad behavior.

The lecturer explains and gives a clear idea of what good behavior is. When the students did inappropriate behavior, the lecturer should make an accurate judgment regarding the bad behavior. The lecturer should have the ability to make good judgments on a variety of situations. He may not bully the students. There is no physical punishments given to the students though the lecturer has authority over the class. The lecturer has to make sure that the students being punished understands that he or she is really fine who is capable of performing the appropriate behavior. The students will learn right from wrong, when they make mistakes and take punishment. The lecturer should always give a chance to the students being punished to perform a desirable activity after punishment. He always motivates the students to do the positive attitude and make the students trust themselves that they are capable of doing it. The punishment is: giving a time out of the class for the student being punished, declining the student's score or grade, etc.

\subsubsection{Appraisals}

Appraisal motivates students to do positive behavior. The students need a clear idea of what positive behavior is and to be positively reinforced when they demonstrate that behavior. The goal of the lecturer in giving appraisal is that he wants the good behavior ( targeted behavior) will be repeated in the future.

Some of ways the lecturer can do 
in giving or showing appraisal are:

1. The lecturer always noted down the name of the students who always did good behavior (targeted behavior)

2. The lecturer always built a good relationship with the students and gives appreciation such as verbal appraisal (good job!, awesome!, etc), and nonverbal communication such as smile, giving applause, etc

3. He gives a privilege honor to the students such as giving a good remark that can be expected in the future when the students consistently doing the targeted behavior

4. He always creative in giving appraisal

\subsubsection{Using the Appropriate Teaching materials and Method Based on the Needs of the Students and the Workplace}

Learning materials and method play the most important roles because the success of the teaching and learning is much influenced by the existing of learning materials and method provided and used by the lecturer and the students. Though it is not easy and simple to do, the lecturer has to develop and design the learning material and the learning method that suitable for the students. To do so, the lecturer must develop and design learning materials and method which consist of learning strategy in line with the students' need and characteristics in order to reach the learning goals. For example in doing a teaching and learning activities, the lecturer applied English for Specific Purposes course that the content and aims of the study are oriented to the specific needs of the English learners in this case the students. The lecturer focus on the genres and the tasks the students need to carry out in English. The lecturer must find out the way for the learners in order to help them succeed in gaining their learning goals.

Before developing the learning materials the lecturer found that the backgrounds of the students are: most of the students (75\%) like English; they (96\%) thought that English is very important for them. There is only $1 \%$ who said that English is not important subject for them. Most of them (52\%) chose Speaking to be learned in the class, while other skills, Reading (21\%), writing (16\%), and Listening (11\%). They $(70 \%)$ said that Speaking in English is very difficult though they don't feel shame to talk in English. There were few students $(23 \%)$ who really feel confident in English speaking skill. Even though they thought that English is very difficult to be learned but some of them $(56 \%)$ don't have special way to overcome the difficulties. Other students said that they tried to learn alone (37\%), talk and learn with peers $(19 \%)$, and registering in an English course (18\%).

After the research done the lecturer should design the learning materials to be learned by the students such as:

1. Finding the kinds of exercises in learning English for Engineering Students such as : speaking with the guiding sentence(s), designing conversations from various materials, translating word(s), sentence(s), and text(s) or/and conversation(s), making a conversation from the available text, working on exercises with sample guidelines, telling the things that are heard, ,etc

2. Finding the topic to be discussed in the process of teaching and learning, such as : machining process, gear design, working machine process, etc

3. Finding the range of vocabularies which are suitable for English for engineering, such as: simple machine concepts, machining tools, engineering materials, electricity, etc.

4. Finding the appropriate tasks for English for engineering students such as: questions and answers, word matching, role play, word connecting, puzzles, etc.

5. Designing the teaching method for the students based on their needs such as 
the design of Task and Genre Based Learning English for Engineering Students with this pattern: introduction ( explanation of each core / unit, personal task, vocabularies, and related grammar), task ( work in personal, work in pair and work in group), Review and the last Self Project

\subsubsection{Discussions}

Being a role model is the first issue. It has a very strong relationship with the findings of some researchers, Nurun (2011) says that giving positive discourse with students, building a good relatonship with difficult students, and giving a respectful and sensitive interactions are the model that the lecturer should show to the students. It is added by Djiwandono (2011) who revealed that the educators should have to poses good inner qualities and good personality that served as a model for the students.

Marja found that in facilitating and supporting the personal chracteristics development, the educators should be paid more attention to the teaching method. integration of character education into curriculum (Lewis et al., 2011). Nurun (2011) added that knowing the students interests is a must in order to boost the students' motivation that will lead to a good start of stage building good characters. It is similar with the this study's finding of using the appropriate materials and methods that relevant to the students currently need and their related future workplace.

Related researchers also found that giving the students meaningful feedback, creating a positive learning and teaching climate (Nurun, 2011), creating a relaxed and favorable classroom atmosphere (Djiwandono, 2011), the importance of community (Harney, 2014) in which similarly in line with the finding of this study, it is building the targeted learning culture and atmosphere.

Finally, giving appraisals and consequences is important in boosting a productive positive characters building, in line with this, though Djiwandono (2011) doesn't put consequences directly, but he said that the teacher (educator) should treat lapses and mistakes with tact, as it is reveled in this study that giving consequences is one of the wise choice of treatment in order to stop the students in doing mistakes, while giving appraisals or praise is a must.

\section{CONCLUSSIONS.}

This study is conducted to discover how the lecturer can implement the character building through instructions. In this stage, the students needs the essential characters such as: having curiosity, being discipline, being innovative, having a good communication, having a good respond to the needs, being innovative, and responsibility. The findings pointed on four main ways that can be implemented by the lecturer to build a good atmosphere in building the student's positive characters needed. Being a role model is the first issue, then followed by building the targeted learning culture and atmosphere, giving apraissals and punishment and finally, is using the appropriate teaching materials and method based on the needs of the students and the workplace.

\section{REFERENCES}

Djiwandono, Patricius.I. (2011). Character Building through Language Learning.Proceeding of "58th TEFLIN International Conference", IKIP PGRISemarang, 5- 7 November 2011, page 44- 48

Hariyanto, Muchlas Samanidan. (2011). Konsep dan Model Pendidikan Karakter. Bandung: Remaja Rosdakarya

Harney,Joshua. (2014). Character Education Integration in Secondary School English Curriculum1Character Education Integration in Secondary School 
English Curriculum https://tspace.library.utoronto.ca/bitst ream/1807/67028/1/Harney_Joshua_ PT_201406_MT_MTRP.pdf

Lewis, S. V., Robinson, E. H. III, \& Hayes, G. (2011). Implementing an authentic character education curriculum.Childhood Education, 87(4), 227-231

Lickona,Thomas (1991). Educating for Character: How Our School Can Teach Respect and Responsibility.New York, Toronto, London, Sydney, Aucland: Bantam books.

Parents-Teachers' Collaboration in Building Students' Positive

Nurun, Mohammed. (2011). ParentTeachers' Collaboration in Building Students'

PositiveManner.https://www.research gate.net/publication/273575285_Char acter_building_Instructions

\section{Online resources:}

http/2018/05/04/formula-4c-untuk-

bertahan- pada-era-revolusi-industri4-0/

http://sumberdaya.ristekdikti.go.id/ind ex.p hp/2018/01/19/pengembangansumber- daya-pendidikan-tinggidalam-era- revolusi-industri-4-0/ https://zakimu.com/blended-learningsolusi-pembelajaran-di-era-revolusiindustri-4-0/

https://www.liputan6.com/bisnis/read/34 25 612/kemenperin-luncurkan-petajalan- making-indonesia-4.0

https://ristekdikti.go.id/kabar/mohamadnasir-harus-siap-hadapi-digitalchallenge- dan-miliki-digitaltalent/\#TIfstZ4KCMuBGiFb.99

https://ristekdikti.go.id/siaran-pers/lantikempat-pimpinan-ptn-menristekdiktiingatkan-perguruan-tinggi-lahirkanlulusan-kompetitif-

2/\#dILGYvIqKgipYte4.99 